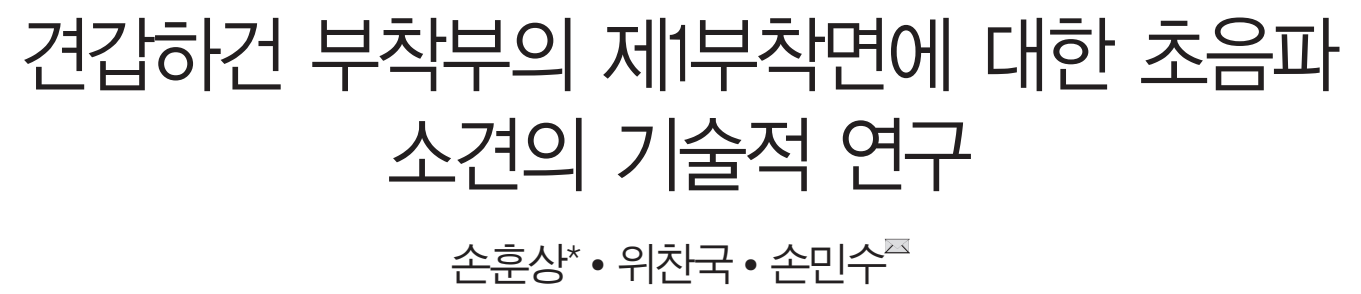

국립중앙의료원 관절센터, 정형외과, ${ }^{\star}$ 연세대학교 원주의과대학 정형외과학교실

\title{
Descriptive Study for Sonographic Morphology of the 1st Facet of Subscapularis Footprint
}

\author{
Hoon-Sang Sohn, M.D.*, Chan Kuk Wi, M.D., and Min Soo Shon, M.D. ${ }^{\circledR}$ \\ Department of Orthopedic Surgery and Center for Joint Surgery, National Medical Center, Seoul, \\ ${ }^{*}$ Department of Orthopedic Surgery, Yonsei University Wonju College of Medicine, Wonju, Korea
}

Purpose: The purpose of this study was to document the sonographic morphology of the subscapularis footprint, particularly the 1st facet, of the non-pathologic subscapularis tendon and footprint, and analyze the correlation between the size of the 1st facet and the demographic variables.

Materials and Methods: Between March 2015 and December 2017, retrospectively data analysis was performed for the ultrasound (US) scans of 115 consecutive shoulder (mean age 53.4 years, range 23-74 years) with non-pathologic subscapularis tendon and footprint. The sonographic findings of the 1st facet of the subscapularis footprint was a very unique, flat, broad, and plane angle in the upward direction, which were distinguished from the other facets. On US, the transverse (medio-lateral) and longitudinal (superior-inferior) length of the 1st facet on axis of the humerus shaft were recorded. The demographic variables, including age, site, body height, weight, body mass index (BMI), and arm length, were reviewed.

Results: On US, the mean transverse length of the 1st facet was $12.75 \mathrm{~mm}$ (range 10.54-14.50 mm, standard deviation [SD] 0.712) and the mean longitudinal length was $12.22 \mathrm{~mm}$ (range $9.20-13.30 \mathrm{~mm}, \mathrm{SD} 0.888$ ). The transverse and longitudinal length of the size of the 1 st facet were significantly greater in males than in females $(p<0.001, p=0.001)$. Of the demographic data (body height, weight, BMI, arm length) that showed a significant positive linear correlation, the correlation with body height (transverse $r=0.749, p<0.001$; longitudinal $r=0.642, p<0.001$ ) showed the strongest relationship, and the correlation with the BMI was weakly related. The relationships between the size of the 1 st facet to site/age were not statistically significant or appeared to have no linear correlation.

Conclusion: The structural and morphologic features of the 1st facet of the subscapularis footprint on the US were identified. This will provide anatomic knowledge of an US examination for subscapularis tendon pathology.

Key words: shoulder, subscapularis, diagnostic ultrasound

Received September 25, 2018 Revised October 22, 2018

Accepted October 26, 2018

Correspondence to: Min Soo Shon, M.D.

Department of Orthopedic Surgery and Center for Joint Surgery, National Medical Center, 245 Eulji-ro, Jung-gu, Seoul 04564, Korea

TEL: +82-2-2262-4707 FAX: +82-2-2278-9570 E-mail: smsice125@naver.com ORCID: https://orcid.org/0000-0002-0012-595X

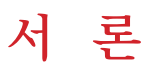

견관절(shoulder joint)의 구조적 안정화와 내회전 및 외전의 운동 에 기여하는 견갑하근(subscapularis)은 회전근개(rotator cuff) 중 가장 크고 강력한 근육이다. ${ }^{1-3)}$ 이러한 견갑하건의 파열은 단독 파열보다는 광범위 파열을 포함하여 극상건을 포함한 다른 회전 근개의 파열과 동반되어 확인되는 경우가 보다 흔한 것으로 알려 
Hoon-Sang Sohn, et al.

져 있고, 또한 외상성 파열보다는 주로 퇴행성 변화의 일환으로 진행되는 경우가 보다 흔한 것으로 보고되고 있다. ${ }^{4-9)}$

그동안 다른 회전근개에 비하여 견갑하건의 파열 빈도는 상당 히 낮은 것으로 보고되고 있었으며 이학적 검사로도 파열을 특이 적으로 구분하여 진단하기 어려운 점이 있어 그 임상적 중요도에 비해 간과된 경향이 있으나 최근 어깨관절에서 관절내시경을 이 용한 수술적 적용의 증가로 인하여 견갑하건의 파열, 특히 건 상 부에서의 관절면 측 부분 파열이 보다 많은 빈도로 관찰되면서 재조명되고 있다. ${ }^{10-13)}$

현재까지는 견갑하건을 포함한 회전근개의 평가를 위한 검사 로는 여전히 자기공명영상이 표준적인 영상의학적 검사로 자리 잡고 있다. ${ }^{14-16)}$ 초음파 검사는 상대적으로 저렴한 검사 비용과 더 불어 비침습적이고, 실시간(real-time) 검사, 역동적(dynamic) 검 사가 가능하다는 장점으로 견관절의 회전근개 등에 대한 영상의 학적 선별검사(screening test)로 최근 널리 자리잡아 가고 있으며, 고해상도 초음파 장비의 발전과 파급 및 진단적 경험의 향상으로 회전근개의 파열에 대한 민감도(sensitivity)와 특이도(specificity) 는 자기공명영상에 필적할 정도로 향상된 것으로 보고되고 있다. 하지만 견갑하건의 경우는 극상건에 비하여 여전히 초음파의 진 단적 민감도와 특이도가 낮게 보고되고 있으며 초음파를 통한 진 단적 연구 역시 보고된 바가 적다. ${ }^{15,17-20)}$

최근 $\mathrm{YoO}$ 등 $^{21)}$ 의 연구에서는 지금까지 2차원적인 관점으로 보 고되어 온 견갑하건의 부착부(footprint)에 대한 사체 해부학 연구 를 통하여 4개의 구별되는 부착면(facet)들로 이루어진 3차원적인 구조를 가지고 있는 것으로 보고하였으며, 그 중 가장 상부에 위 치하고 있는 제1부착면(first facet)은 부착면들 중 가장 우세한 생 역학적 기능을 담당하고 있으면서 가장 파열이 흔히 발생되는 부 위이고 퇴행성 파열이 시작되는 부위로 보고하고 있다.

따라서 초음파상 가장 뚜렷하게 반사되어 고에코(hyperechoic) 의 음영으로 확인할 수 있는 골조직의 특성을 고려하여 견갑하건 의 병변이 주로 발생되는 해부학적 위치에 대한 이해와 견갑하건 의 평가의 표지점(landmark)이 되는 부착부의 3차원적 위치를 이 해하고 정적 및 동적 초음파 검사를 시행하게 된다면 견갑하건의 평가에 대한 초음파적 유용성을 보다 높일 수 있을 것으로 생각 되며, 이에 본 연구에서는 병변이 없는 견갑하건 부착부를 가진 환자를 대상으로 초음파를 통한 견갑하건의 부착부, 특히 제1부 착면에 대한 초음파적 영상 소견 및 그 크기를 기술하고 인구통 계적 특성과의 상관관계를 분석하고자 하였다.

\section{대상 및 방법}

\section{1. 연구대상}

2015년 3월부터 2017년 12월까지 본원(국립중앙의료원)에 입원 또는 외래로 방문하여 견관절 또는 관절 주변의 통증을 호소하였
던 환자들에 대한 진단적 접근과정에서 견갑하건과 그 부착부에 서의 병변이 없는 것으로 확인된 환자들을 대상으로 하여 후향적 분석(retrospective analysis)을 시행하였다.

모든 환자들은 철저한 병력청취 및 이학적 신체검진을 시행하 였고 견관절에 대한 방사선적 검사(shoulder antero-posterior [AP], glenohumeral AP, caudal tilt view, Y-view, axillary view)를 촬영하 였으며 이후 견관절의 초음파 검사를 시행하였다. 그 평가과정에 서 병력청취 또는 단순 방사선학적 소견상 이전 근위 상완골에 서의 골절이나 탈구 등의 외상력 및 그로 인한 수술적 치료 병력, 이전 회전근개 파열 등으로 인한 수술적 치료 병력, 초음파 검사 상 견갑하건 자체의 부분 파열 또는 완전층 파열, 단순방사선적 또는 초음파 검사상 소견상 견갑하건의 부착부인 소결절(lesser tuberosity)의 골표면의 불규칙 또는 낭종성 병변(any bony change including cortical irregularity or cystic change)의 확인, 유착성 관 절낭염을 포함한 어깨질환으로 인한 관절 가동 범위에서의 제한 으로 단순방사선적 검사 또는 초음파 검사를 위한 자세를 취하기 어려워 평가에 제한을 보이는 경우, 일차성 관절염 또는 회전근 개 관절병증의 소견, 화농성 및 결핵성 관절염, 또는 류마티스 및 염증성 관절병증 등의 병력, 종양 또는 종양-유사 병변, 뇌졸증, 상완신경총병증 및 그 외 다른 신경병증으로 인하여 어깨관절 내 근-건 단위(musculotendinous unit)의 구조적 변화를 초래할 수 있 는 질환 등 견갑하건과 그 부착부의 병변이 의심 또는 확인되거 나 평가에 영향을 줄 수 있는 경우는 대상에서 제외하기로 하였 으며, 최종적으로 견갑하건 부착부에서의 병변이 의심되지 않은 총 115 명의 환자군을 최종 연구대상으로 하였다. 대상 환자군의 평균 연령은 53.4세(범위, 23-74세)였고, 남자가 71예, 여자가 44예 였으며, 우측 어깨가 68예, 좌측 어깨가 47예였다(Table 1).

\section{2. 초음파 검사 및 평가 방법}

철저한 병력청취, 이학적 신체검진 및 방사선적 검사 후 이상 소 견 여부를 확인한 뒤 진단적 초음파 검사를 시행하였다. 초음파

Table 1. Patient Demography $(n=115)$

\begin{tabular}{lc} 
& \multicolumn{1}{c}{ Variable } \\
Age $(\mathrm{yr})$ & $53.4 \pm 13.26(23-74)$ \\
Sex (male:female) & $71: 44$ \\
Site (right:left) & $68: 47$ \\
Height $(\mathrm{cm})$ & $165.50 \pm 7.69(147-180)$ \\
Weight $(\mathrm{kg})$ & $64.31 \pm 11.14(49-105)$ \\
Body mass index $\left(\mathrm{kg} / \mathrm{m}^{2}\right)$ & $23.29 \pm 2.60(16.3-32.4)$ \\
Arm length $(\mathrm{cm})^{\star}$ & $53.27 \pm 3.31(47-60)$ \\
\hline
\end{tabular}

Values are presented as mean \pm standard deviation (range) or number only. *Length between anterolateral margin of acromion and radial styloid tip on anatomical position. 
검사는 z.one Ultra-Convertible ultrasound ${ }^{\mathrm{TM}}$ system (ZONARE Medical System, Inc., Mountain View, CA, USA) 및 고주파수 선형 변환기(L14-5W; linear array transducer with high frequency)를 이 용하여 시행되었으며, 5 년 이상의 진단적 및 중재적 근골격계 초 음파의 경험을 가진 한 명의 정형외과 전문의(S.M.S)에 의해 평가 를 시행하고 분석을 하였다.

견관절의 초음파 검사는 환자의 검사하고자 하는 어깨의 앞 쪽 에 검사자가 다소 비스듬히 앉아서 시행하였고, 표준적인 검사방 법에 준하여 전방, 측방, 후방 및 상부의 4구획으로 나누어 순서 대로 검사를 진행하였으며, 견갑하건과 그 부착부에 대한 초음 파 평가는 어깨의 전방구획의 평가에서 시행되었다. 검사의 시작 점이자 해부학적인 표지점인 이두구(bicipital groove) 내에 위치 한 상완 이두건 장두(biceps long head tendon)의 단축(short axis, transverse view)과 장축(long axis, longitudinal axis)을 검사하여 이 두건 장두의 위치와 병변 여부를 확인하였고, 이후 이두건 장두 의 단축을 검사하기 위한 환자의 자세와 변환기의 위치에서 변 환기를 다소 내측으로 이동시키게 되면 상완 이두건 장두, 오구 돌기(coracoid process)를 동시에 검사할 수 있으며, 두 구조물 사 이에서 위치하고 있는 소결절와 그에 부착된 견갑하건을 확인할
수 있다. 이 상태로 변환기를 유지한 상태로 환자의 견관절을 외 회전시키면서 상완 이두건 장두의 안정성 여부, 상완 이두건 장 두와 견갑하건과의 관계, 견갑하건의 부착부에서의 동적 영상을 철저하게 확인하게 된다. 견관절의 외회전은 견갑하건의 경우 그 건조직이 압박-신장되고, 건의 부착부는 변환기와 최대한 수평 으로 놓이게 되어 각 조직들에 대한 비등방성 인공물(anisotropy) 을 최소화할 수 있게 됨으로써 환자에 따라 외회전의 정도는 부 착부인 소결절이 가장 수평으로 위치하게 되는 정도까지 시행해 준다. 이 상태에서의 영상은 견갑하건에 대해서는 장축, 견갑하 건의 부착부에 대해서는 단축임을 인지하면서 변환기를 위-아래 로 이동시키며 견갑하건과 그 부착부에 대한 전장을 확인하게 된 다. 위에서 아래로 검사할 때 견갑하건의 부착부의 굴곡된 모양 이 일정한 형태의 변화를 보이고 있는 것을 확인할 수 있으며 가 장 상부의 제 1 부착면은 보다 평편한 구조를 가지고 있어 제 2 부착 면 이하 부착면들과 뚜렷하게 구별할 수 있게 된다. 이러한 제 1 부 착면에서 가장 평편하고 넓은 부분을 확인하여 그 길이를 측정 하며 이를 제 1 부착면의 횡적 길이(transverse length, medio-lateral length)로 정의하였다(Fig. 1).

이후 변환기를 90 도 회전시키면서 견갑하건에 대해서는 단축
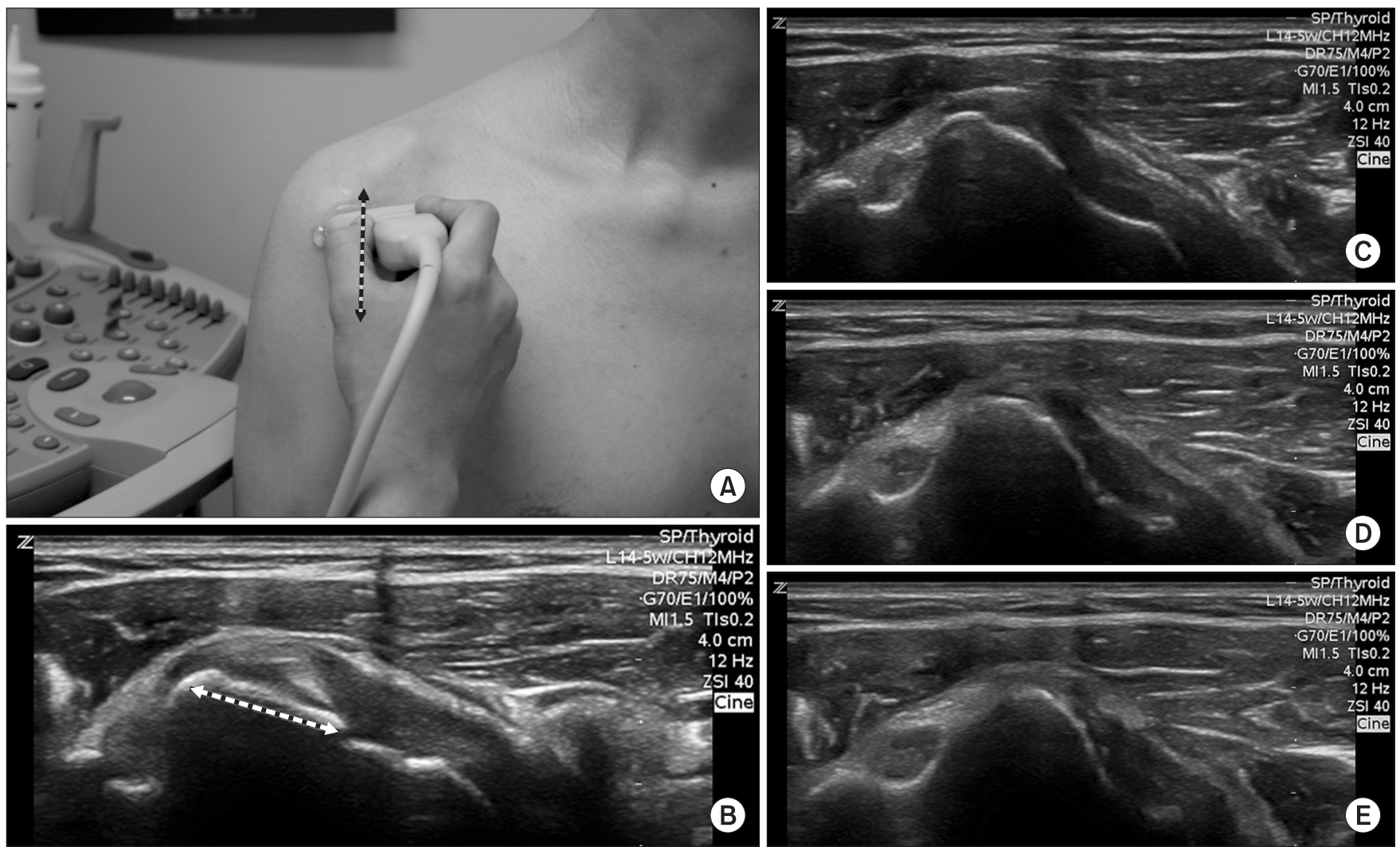

(A)

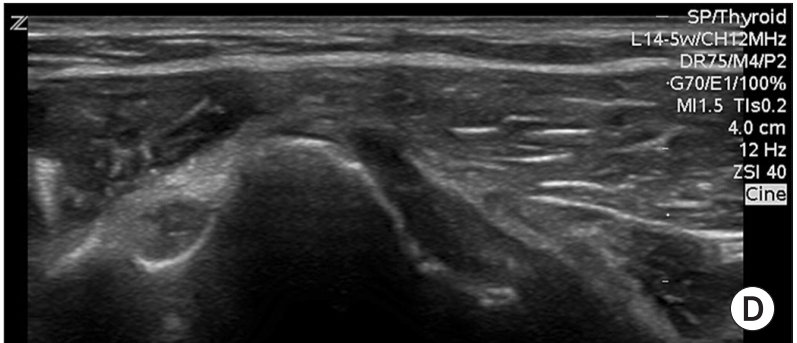

Figure 1. (A) Transverse scans of the subscapularis footprint (same as longitudinal scan of subscapularis tendon) tracing from superior to inferior (B-E) on the axis of humerus shaft. The sonographic morphology of the 1st facet of subscapularis footprint was unique with its flat and broad shape, which were distinguished from the other facets. The longest length was measured on a transverse scan of the 1st facet (transverse or medio-lateral length). 

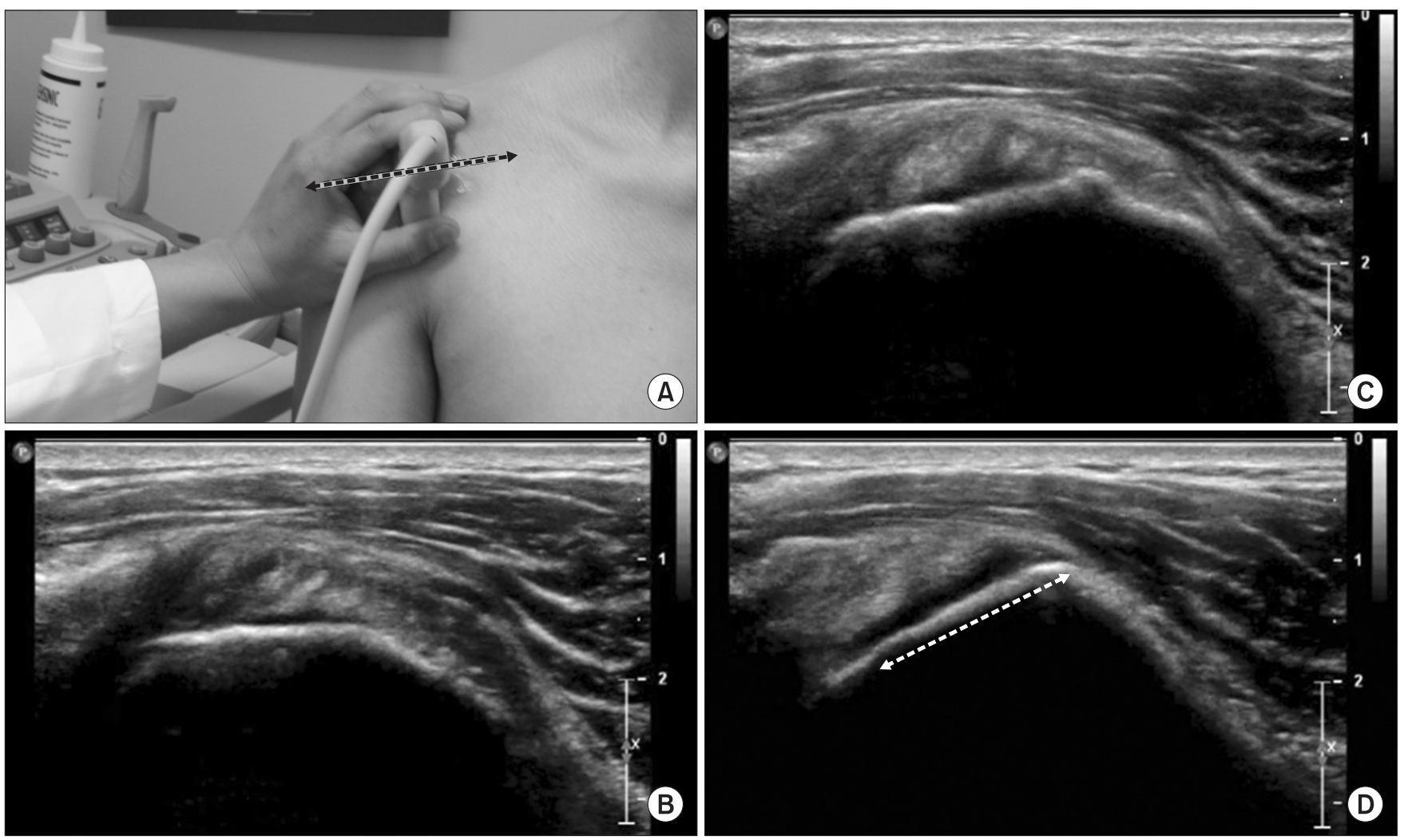

Figure 2. (A) Longitudinal scans of the subscapularis footprint (same as transverse scan of subscapularis tendon) tracing from medial to lateral (BD) on axis of humerus shaft. The shapes of the tendinous portion of the subscapularis have undergone gradual echogenic and morphologic changes. On the medial portion $(\mathrm{A}, \mathrm{B})$, the corresponding ultrasound images of the subscapularis tendon revealed its multipennate appearance showing areas of hyper- and hypo-echogenicity. The echogenicity of the subscapularis tendon became denser and more hyperechoic as the tendon was closer to the 1st facet of the subscapularis footprint. The 1st facet of the subscapularis footprint also has a plane angle in the upward direction, which was distinguished from other facets with the plane angle in the anterior direction.

영상을, 부착부에 대해서는 장축 영상을 검사할 수 있다. 정상적 인 건의 경우 고에코의 다발과 사이의 저에코의 틈새(cleft)를 관 찰할 수 있는데 이는 건 섬유속(fascicle) 사이로 근섬유가 위치하 여 보이는 현상(multipennate appearance)으로 견갑하건의 근-건 구조의 특성으로 알려져 있는 소견으로서, 이 소견이 확인되는 부위에서 보다 외측으로 변환기를 천천히 이동시키면서 부착부 를 관찰하게 되면 평편한 형태로 3 차원적으로 다른 하부 부착면 들에 비해 상방으로 향하고 있는 제 1 부착면을 확인할 수 있게 된 다. 또한 그에 부착되어 있는 근-건 구조의 특성이 앞서 기술된 견갑하건에서의 특징적인 mulitpennate 현상이 사라지고 보다 균 일한 건조직의 고에코의 영상이 강해지는 것을 확인할 수 있으 며 바로 외측에는 이두구와 이두박건 장두가 위치하고 있는 것으 로 확인할 수 있다. 이 상태에서의 영상은 견갑하건에 대해서는 단축, 견갑하건의 부착부에 대해서는 장축임을 인지하면서 변환 기를 내측-외측으로 이동시키면서 견갑하건과 그 부착부에 대 한 전장을 확인하게 된다. 이러한 제 1 부착면의 장축 영상에서는 3 차원적으로 다른 하부 부착면들에 비해 상방으로 향하고 있는
해부학적 특성상 환자의 견관절을 약간 신전시키거나 변환기를 다소 기울여(tilting) 검사하게 되면 제 1 부착면과 변환기가 수평으 로 위치하게 됨으로써 그에 부착되어 있는 건조직에서의 비등방 성 인공물을 최소화하면서 검사를 할 수 있게 된다. 이때의 제 1 부 착면의 길이를 측정하며 이를 제 1 부착면의 종적 길이(longitudinal length, supero-inferior length)로 정의하였다(Fig. 2). 이러한 제1부 착면의 종축 영상은 이두박건 장두의 종축(장축) 영상을 검사한 상태에서 변환기를 내측으로 천천히 이동시키면서 확인할 수도 있다(Fig. 3).

각 환자는 견갑하건의 부착부에 대한 초음파의 평가와 더불어 나이, 성별, 키, 체중, 체질량지수(body mass index, BMI) 및 팔 길 이(해부학적 자세에서 전외측 견봉극에서 요골 경상돌기까지의 길이)를 측정하였다.

\section{3. 통계적 분석}

본 연구에서 모든 통계적 분석은 PASW ver. 18.0 for Windows (IBM Corp., Armonk, NY, USA)를 이용하여 분석하였고 유의수 

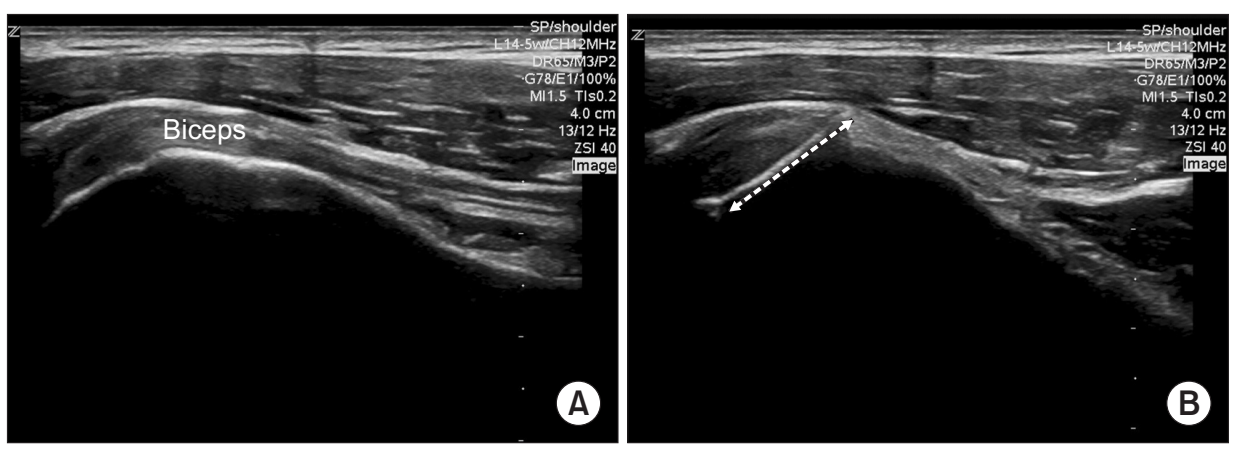

Figure 3. Longitudinal scans of subscapularis 1st facet tracing from longitudinal scan of biceps long the head tendon (A) to just medial on the axis of humerus shaft (B).

Table 2. Comparison of the Patient's Sex/Site and Length of Subscapularis the 1st Facet

\begin{tabular}{lcc} 
Variable & M-L length $(\mathrm{cm})$ & S-I length $(\mathrm{cm})$ \\
Sex & & \\
Male & $13.14 \pm 0.58$ & $12.26 \pm 0.62$ \\
Female & $12.29 \pm 0.61$ & $11.63 \pm 1.07$ \\
p-value & $<0.001^{*}$ & $0.001^{*}$ \\
Site & & \\
Right & $12.84 \pm 0.78$ & $11.97 \pm 0.89$ \\
Left & $12.77 \pm 0.59$ & $12.16 \pm 0.88$ \\
p-value & 0.616 & 0.276 \\
\hline
\end{tabular}

Values are presented as mean \pm standard deviation. *Statistically significant difference $(\mathrm{p}<0.05)$. M-L, medio-lateral; S-I, superior-inferior.

준은 $p<0.05$ 로 하였다. 각 평균과 표준편차는 기술통계(descriptive statistics)로 분석하였고, 성별간 및 좌우 부위간 1 부착면의 길 이(횡적 길이와 종적 길이)의 차이는 독립표본 t-검정(independent t-test), 나이, 키, 체중, BMI 및 팔 길이의 인구통계 요소와 제1부착면의 길이와의 상관관계는 피어슨 상관 분석(Pearson's correlation analysis)으로 분석하였다.

\section{결 과}

초음파 검사를 통하여 측정된 견갑하건의 제 1 부착면의 평균 횡 적 길이는 $12.75 \mathrm{~mm}$ (범위 $10.54-14.50 \mathrm{~mm}$, 표준편차 0.712), 평균 종적 길이는 $12.22 \mathrm{~mm}$ (범위 9.20-13.30 mm, 표준편차 0.888)였다.

성별간 견갑하건의 제 1 부착면의 크기는 종적 길이와 횡적 길 이 모두에서 남성에서 유의하게 큰 것으로 확인되었으며, 이러 한 성별간의 차이는 성별간 키의 차이(남자 $168.85 \pm 6.28 \mathrm{~cm}$, 여자 $159.12 \pm 5.93 \mathrm{~cm} ; \mathrm{p}<0.001)$ 또는 팔 길이의 차이(남자 $54.83 \pm 2.54$ $\mathrm{cm}$, 여자 $49.75 \pm 1.75 \mathrm{~cm} ; \mathrm{p}<0.001)$ 에서 비롯된 것으로 보여진다. 실제 좌우 부위간 제 1 부착면의 크기는 차이를 보이지는 않았다 (Table 2).

인구통계학적 요소 중 나이와 견갑하건의 제 1 부착면의 크기는
선형의 상관관계를 보이지는 않는 것으로 분석되었으며(횡적 길 이 $r=-0.178, p=0.253$; 종적 길이 $r=-0.104, p=0.506)$, 양성의 선형 상 관관계(positive linear correlation)를 보이는 요소들 중 견갑하건의 제 1 부착면의 종적 및 횡적 크기 모두에서 키와 가장 강한 양성 선 형관계(strong positive correlation)를 보였고, BMI와는 약한 양성 선형관계(weak positive correlation)를 보이고 있는 것으로 분석되 었다(Fig. 4, 5).

\section{고 찰}

본 연구에서는 견갑하건의 부착부에 대한 초음파 검사를 통하여 부착부의 골 표면의 초음파적 음영의 형태적 특성을 통하여 일관 되게 평편한 면을 보이는 상부의 제1부착면을 확인하였고 제2부 착면 이하 하부에 위치한 부착면과는 구별되는 형태와 경사를 보 이고 있는 것으로 관찰할 수 있었으며, 그 크기는 평균 $12.75 \times 12.22$ $\mathrm{mm}$ 의 길이를 가지고 있는 것으로 평가되었다. 최근 Yoo 등 ${ }^{21)}$ 은 39예의 사체 해부 연구를 통하여 서로 다른 4개의 부착면(different planes of insertion to the lesser tuberosity, termed 'facet')으로 이루어진 3차원적인 형태의 견갑하건의 부착부를 기술하였으며 가장 상부에 위치하는 제 1 부착면은 평균 $13.8 \times 13.5 \mathrm{~mm}$ 의 길이로 전체 부착부의 $34 \%$ 를 차지하고 있는 것으로 보고하였고, 본 연구 에서 초음파 검사를 통하여 확인된 제 1 부착면의 형태 및 크기와 도 부합하고 있는 것으로 판단된다. 또한 본 연구에서는 제1부착 면의 각 축에서의 길이(또는 크기)는 성장이 끝난 이후 연령대나 좌우 부위와의 상관관계는 보이지 않았으며 골조직 자체의 성장 과 그 형태, 크기에 직접적으로 비례하는 키, 체중(또는 팔 길이, $\mathrm{BMI})$ 의 인구통계적 요소들과 양의 선형 상관관계를 보이는 것으 로 평가되었다.

회전근개 중 가장 크고 강력한 건인 견갑하건은 어깨관절의 전 방을 주행하여 건의 부착부인 근위 상완골의 소결절에 부착하며, 견관절의 내회전 및 외전의 기능과 안정화에 기여하고 있는 구 조물이다. 또한 특징적인 근-건 단위의 구조적 특성을 가지고 있 는 바, 근육 내 4-6개의 콜라겐 섬유 다발들로 이루어진 건가닥들 (tendon slips)이 존재하며 부착부에 가까워질수록 상방 전이되면 
Hoon-Sang Sohn, et al.
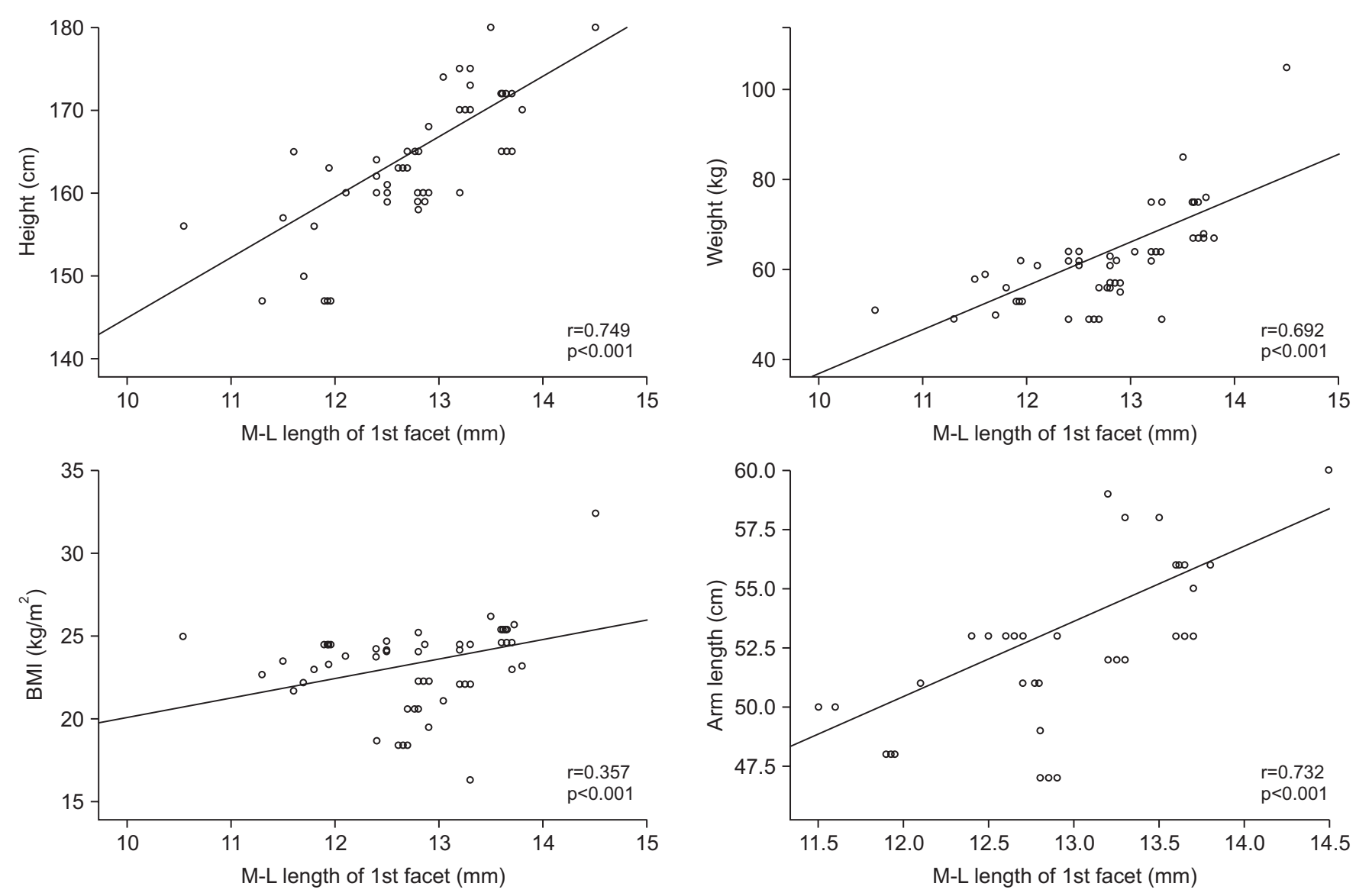

Figure 4. Correlation analysis between the demographic data and the medio-lateral (M-L) length of the subscapularis 1st facet on ultrasound. $r$, Pearson correlation coefficient; BMl, body mass index.

서 건가닥들이 모여들어 띠 형태의 건대(tendinous band)를 이루 어 부착부의 상부 $2 / 3$ 에 부착되고, 나머지 하부 $1 / 3$ 에는 근조직으 로 부착되는 것으로 알려져 있다. 22,23)

회전근개의 부착부에 대한 이해는 회전근개의 생역학적 특성 및 회전근개의 파열과 그에 대한 봉합술에 있어서의 해부학적 기 초를 정립하는데 그 임상적 타당성이 있다 할 수 있으며, 견갑하 건의 부착부에 대해서도 몇몇 연구들이 보고된 바 있다. ${ }^{24-27)}$ 특히 Arai 등 ${ }^{24}$ 과 Ide 등 ${ }^{26}$ 의 견갑하건 부착부에 대한 사체 해부학 연구 들에서는 상부의 부착부가 보다 넓고 크며 하부로 갈수록 점차 좁아지는 형태를 보이고 있다고 보고하였다. 이러한 기존의 연구 들은 $\mathrm{YoO}$ 등 ${ }^{21)}$ 의 견갑하건의 3차원적 부착부의 형태와는 달리 2 차원적인 형태를 기술하였다는 단점이 있으나 그 형태적 특성에 서 상부 부착부의 생역학적 기능적 특성에 대한 중요성을 강조하 였다는 점에서는 서로 부합하고 있다. 특히 Yoo 드이은 3차원적 인 형태의 견갑하건의 부착부 중 가장 상부에 위치하고 있는 제1 부착면은 제2부착면 이하 다른 부착면들 중 전체 견갑하건의 부 착부의 $1 / 3$ 을 차지할 정도의 가장 넓은 면적을 가지고 있으며, 극 상건의 부착면에 가깝게 상향을 향하고 있는 편평한 구조를 보이
고 있는 것으로 보고하고 있다. 이러한 3차원적으로 구별되는 부 착면들은 생역학적 힘의 전달을 위한 근-견인선들과 연관된 구 조적 특성을 시사한다고 주장하였으며 제 1 부착면이 가장 우세한 생역학적 기능을 담당하고 있으면서 특히 다른 부착면들과는 달 리 제 1 부착면의 경우 회전의 기능보다는 외전(견갑축상에서의 거상)에 보다 중요한 기능을 담당할 것이라고 주장하였다. 이러 한 제 1 부착면의 형태적 특성과 연관된 생역학적 특성은 기존의 여러 해부학적, 생역학적 및 임상적 연구들의 결과와도 부합하고 있다. ${ }^{28-30)}$ Halder 등 ${ }^{28}$ 의 견갑하건의 부위별 구조적 특성의 차이 를 알아보기 위한 사체 생역학 연구에서는 견갑하건을 4구획(상 부, 중간-상부, 중간-하부, 하부)으로 분류하여 평가하였을 때 하 부에 비하여 상부에서 강성(stiffness)과 최대 하중(ultimate load)이 더 높으며 하부에서 가장 낮은 파괴 하중(failure load) 및 강성을 보였다고 보고하고 있다. 또한 $\mathrm{Omi}$ 등 ${ }^{30)}$ 의 연구에서도 상부와 하 부의 건 부위가 서로 다른 기능을 담당하고 있으며 상부 $1 / 3$ 의 건 부위가 견갑축 상에서 팔의 거상 기능에 중요한 기능할 것으로 보고한 바 있다.

견갑하건의 제 1 부착면의 임상적 중요성 중 하나는 그 해부학 

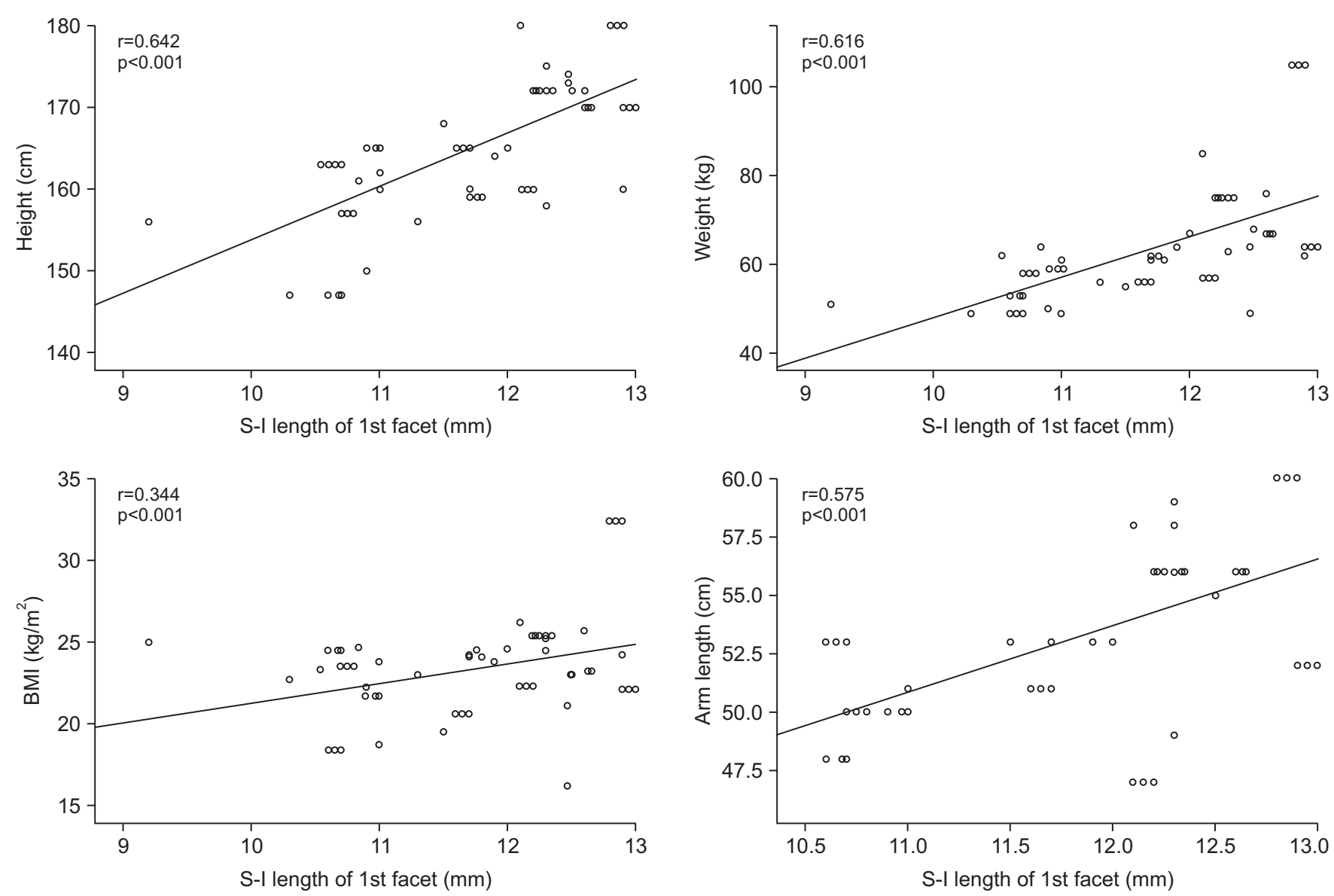

Figure 5. Correlation analysis between the demographic data and the superior-inferior (S-I) length of the subscapularis 1st facet on ultrasound. $r$, Pearson correlation coefficient; BMl, body mass index.

적, 생역학적 기능에 부합하여 가장 파열이 흔히 발생되는 부위 이면서 퇴행성 파열이 시작되는 부위라는 점이며 이는 최근 관 절 내시경적 수술의 증가 추세에 맞추어 견갑하건의 파열, 특히 관절면측 부분파열이 많은 빈도로 확인되고 있으며, 그에 부합하 여 최근 연구에 의하면 견갑하건의 파열은 약 $59 \%$ 까지도 보고되 고 있다. ${ }^{60-13)}$ 또한 Yoo 등 ${ }^{21)}$ 의 최근 연구에서는 3차원적인 부착 면의 침범 정도를 기준으로 한 견갑하건의 파열 분류에 대한 연 구가 이루어졌으며 저자들은 관절내시경 수술과정에서 약 $50.5 \%$ (415/821)의 견갑하건의 파열을 확인할 수 있었으며 그 중 제 1 부 착면을 침범한 파열은 약 $77.9 \%$ 에 달하며 가장 많은 형태가 제 1 부착면의 $50 \%$ 이하를 침범한 부분 파열의 형태(29.4\%)로 보고하 였다. 또한 이러한 견갑하건의 파열은 연령과 통계적 유의성을 보이면서 연령이 높아질수록 그 빈도가 증가되는 것으로 보고하 였다.

다른 회전근개에서와 마찬가지로, 견갑하건의 파열에 대한 진 단율의 향상은 치료방법의 결정과 그 예후에 중요한 역할을 하게 된다. 하지만 Jang 등 ${ }^{31}$ 의 견갑하건 파열의 정도와 신체검진 및 근 력검사와의 상관관계 연구에서도 보고된 바와 같이 관절면측 부
분 파열을 포함한 상부 일부분만을 침범한 견갑하건의 파열의 경 우 신체검진상 이상 소견이 뚜렷하지 않아 진단하기가 더욱 어려 워지고, 견갑하건의 파열은 대부분 다른 회전근개의 파열과 동반 되어 발생되며 많은 경우 다른 회전근개 파열에 대한 수술적 치 료과정에서 확인되면서 수술 중 치료방법을 결정해야 되는 경우 들이 있다. 따라서 철저한 병력청취 및 임상적 평가와 더불어 수 술전 영상검사를 통한 견갑하건의 상태에 대한 철저한 평가는 매 우 중요하다 할 수 있다.

회전근개에 대한 초음파의 진단율은 최근 고해상도 초음파 장 비의 도입과 검사 수준의 향상으로 높은 민감도와 특이도를 보이 는 것으로 보고되고 있다. 하지만 그간의 연구 보고는 대부분 극 상건과 극하건에 집중된 연구 결과이며, 특히 견갑하건에 대하여 단독으로 평가된 초음파 연구는 극히 적으며, 부분 파열을 포함 한 상부의 일부분을 침범한 파열 형태에 대한 진단적 성적은 여 전히 낮은 것으로 보고되고 있다. ${ }^{15,17-20)}$ Narasimhan 등 ${ }^{17}$ 의 최근 연구에서는 관절내시경으로 최종 확인된 견갑하건의 파열(31.4\%, 74/236)에서 수술 전 시행된 초음파의 진단율 평가 시 전체의 정 확도(overall accuracy)는 $75.8 \%$, 양성예측도(positive predictive 
Hoon-Sang Sohn, et al.

value)는 $73.1 \%$, 음성예측도(negative predictive value)는 $76.4 \%$ 였 으며 전체의 특이도는 $93.1 \%$ 로 높은 반면 민감도는 $39.5 \%$ 로 낮게 평가되었다. 특히 Laffosse 분류상 제 3 유형 이상의 상부 $2 / 3$ 를 침 범한 완전파열에서는 $75 \%$ 의 민감도를 보였던 반면, 상부 $1 / 3$ 이 하의 부분 또는 완전파열에서는 $27.8 \%$ 의 낮은 민감도를 보이는 것으로 보고하였다. 이러한 소견은 최근 보고되고 있는 다른 연 구의 결과와도 부합한다. ${ }^{14-16,18-20)}$ 따라서 저자들은 이러한 제1부 착면의 임상적 중요성을 고려해 제 1 부착면을 견갑하건에 대한 평가의 표지점으로 설정하여 우선적으로 정확하게 제 1 부착면의 위치를 확인하고, 그 부착면에 부착된 견갑하건의 음영을 전장 에 걸쳐 철저하게 검사하면서 평가하는 것이 중요하며, 본 연구 를 통하여 견갑하건에 대한 초음파적 진단에 대한 해부학적 기초 자료를 제공함으로써 상부의 완전파열뿐 아니라 부분파열에서의 초음파의 진단적 민감도와 특이도를 높일 수 있다고 생각한다.

본 연구는 후향적 연구라는 점과 그 연구 결과를 일반화하기 에는 그 대상 환자수가 충분치 않다는 점과 더불어 몇 가지 한계 점을 가지고 있다. 우선 모든 초음파 검사와 평가가 한 명의 전문 의에 의해서만 시행된 연구 결과이며 실시간으로 시행되는 초음 파 검사의 특성으로 인하여 관찰자 간 또는 관찰자 내 신뢰도(interobserver or intraobserver reliability)를 평가하지는 못하였다. 하 지만 평가를 시행한 전문의는 어깨관절에 대한 초음파 검사에 대 하여 수년간의 경험을 가지고 있으며 본 연구를 시행하기 전 예 비 연구를 시행하여 평가방법의 결정을 포함한 준비과정을 거친 이후 본 연구의 대상군 설정과 동일한 평가방법을 이용하여 연구 를 시작하여 그 오차를 최소화시키고자 하였다. 또한 견갑하건과 그 부착부에 대하여 초음파 검사만을 시행하여 평가된 결과이며, 그 외 컴퓨터단층촬영, 자기공명영상 또는 수술 중 확인된 내시 경 소견에서의 결과와의 연관성 및 타당도는 평가하지 못하였다. 이에 대해서는 향후 추가적인 연구가 필요할 것으로 보인다. 마 지막으로 3차원적인 구조를 2차원적인 단면으로 보여주는 초음 파의 한계상 제 1 부착면의 길이를 평가함에 있어 공통적으로 적 용할 수 있는 기준점을 설정하지 못하였고 각각의 평가에서 초음 파로 검사하는 각도에 따라 그 단면상 길이의 오차를 보일 수 있 으며 그 영상과 실제 부착부의 각 축과 일치하지 않을 가능성이 있다. 다만 이러한 측정상의 오차를 최대한 줄이기 위하여 각각 의 초음파 평가에서 제 1 부착면의 전장을 최대한 자세히 검사하 면서 가장 긴 장축을 기준으로 그 길이를 평가하였으며 실시간으 로 이루어지는 초음파 검사에서 최소 2 번 이상 확인하는 과정을 거쳤다.

\section{결 론}

병변이 없는 견갑하건과 그 부착부의 초음파적 영상 평가를 시행 하여 그 부착부에 대한 구조와 형태적 특성을 확인할 수 있었으
며, 특히 가장 상부의 제 1 부착면의 일관성 있는 형태와 크기를 확 인할 수 있었다. 이러한 제1부착면을 포함한 견갑하건의 부착부 의 확인과 그에 부착된 견갑하건 부위에 대한 철저한 초음파적 평가는 견갑하건 파열에 대한 진단적 검사에 대한 해부학적 기초 를 제공하게 될 것이며, 이를 통한 견갑하건 파열의 진단적 검사 로서 초음파적 진단의 정확도, 민감도와 특이도를 높일 수 있을 것으로 생각된다.

\section{CONFLICTS OF INTEREST}

The authors have nothing to disclose.

\section{REFERENCES}

1. Dyrna F, Kumar NS, Obopilwe E, et al. Relationship between deltoid and rotator cuff muscles during dynamic shoulder abduction: a biomechanical study of rotator cuff tear progression. Am J Sports Med. 2018;46:1919-26.

2. Gamulin A, Pizzolato G, Stern R, Hoffmeyer P. Anterior shoulder instability: histomorphometric study of the subscapularis and deltoid muscles. Clin Orthop Relat Res. 2002;398:121-6.

3. Keating JF, Waterworth P, Shaw-Dunn J, Crossan J. The relative strengths of the rotator cuff muscles. A cadaver study. J Bone Joint Surg Br. 1993;75:137-40.

4. Adams CR, Schoolfield JD, Burkhart SS. The results of arthroscopic subscapularis tendon repairs. Arthroscopy. 2008;24:1381-9.

5. Flury MP, John M, Goldhahn J, Schwyzer HK, Simmen BR. Rupture of the subscapularis tendon (isolated or in combination with supraspinatus tear): when is a repair indicated? J Shoulder Elbow Surg. 2006;15:659-64.

6. Jeong JY, Pan HL, Song SY, Lee SM, Yoo JC. Arthroscopic subscapularis repair using single-row mattress suture technique: clinical results and structural integrity. J Shoulder Elbow Surg. 2018;27:711-9.

7. Kim SJ, Choi YR, Jung M, Lee W, Chun YM. Arthroscopic repair of anterosuperior massive rotator cuff tears: does repair integrity affect outcomes? Am J Sports Med. 2017;45:1762-8.

8. Kim YK, Kim DW, Noh YT, Lee SB. Arthroscopic repair of combined rotator cuff tears involving the subscapularis tendon. J Korean Orthop Assoc. 2010;45:392-8.

9. Warner JJ, Higgins L, Parsons IM 4th, Dowdy P. Diagnosis and treatment of anterosuperior rotator cuff tears. J Shoulder 
Elbow Surg. 2001;10:37-46.

10. Denard PJ, Burkhart SS. Arthroscopic recognition and repair of the torn subscapularis tendon. Arthrosc Tech. 2013;2:e3739.

11. Gerhardt C, Bartl C, Voigt C, et al. Recovery of subscapularis and shoulder function following arthroscopic treatment of isolated anterior and combined anterosuperior rotator cuff lesions. Arch Orthop Trauma Surg. 2016;136:75-81.

12. Lafosse L, Jost B, Reiland Y, Audebert S, Toussaint B, Gobezie R. Structural integrity and clinical outcomes after arthroscopic repair of isolated subscapularis tears. J Bone Joint Surg Am. 2007;89:1184-93.

13. Lo IK, Burkhart SS. The comma sign: an arthroscopic guide to the torn subscapularis tendon. Arthroscopy. 2003;19:3347.

14. Adams CR, Schoolfield JD, Burkhart SS. Accuracy of preoperative magnetic resonance imaging in predicting a subscapularis tendon tear based on arthroscopy. Arthroscopy. 2010;26:1427-33.

15. Alilet M, Behr J, Nueffer JP, Barbier-Brion B, Aubry S. Multi-modal imaging of the subscapularis muscle. Insights Imaging. 2016;7:779-91.

16. Ryu HY, Song SY, Yoo JC, Yun JY, Yoon YC. Accuracy of sagittal oblique view in preoperative indirect magnetic resonance arthrography for diagnosis of tears involving the upper third of the subscapularis tendon. J Shoulder Elbow Surg. 2016;25:1944-53.

17. Narasimhan R, Shamse K, Nash C, Dhingra D, Kennedy S. Prevalence of subscapularis tears and accuracy of shoulder ultrasound in pre-operative diagnosis. Int Orthop. 2016;40:975-9.

18. Roy JS, Braën C, Leblond J, et al. Diagnostic accuracy of ultrasonography, MRI and MR arthrography in the characterisation of rotator cuff disorders: a systematic review and meta-analysis. Br J Sports Med. 2015;49:1316-28.

19. Rutten MJ, Jager GJ, Kiemeney LA. Ultrasound detection of rotator cuff tears: observer agreement related to increasing experience. AJR Am J Roentgenol. 2010;195:W440-6.
20. Teefey SA, Middleton WD, Payne WT, Yamaguchi K. Detection and measurement of rotator cuff tears with sonography: analysis of diagnostic errors. AJR Am J Roentgenol. 2005;184:1768-73.

21. Yoo JC, Rhee YG, Shin SJ, et al. Subscapularis tendon tear classification based on 3-dimensional anatomic footprint: a cadaveric and prospective clinical observational study. Arthroscopy. 2015;31:19-28.

22. Clark JM, Harryman DT 2nd. Tendons, ligaments, and capsule of the rotator cuff. Gross and microscopic anatomy. J Bone Joint Surg Am. 1992;74:713-25.

23. Klapper RC, Jobe FW, Matsuura P. The subscapularis muscle and its glenohumeral ligament-like bands. A histomorphologic study. Am J Sports Med. 1992;20:307-10.

24. Arai R, Sugaya H, Mochizuki T, Nimura A, Moriishi J, Akita K. Subscapularis tendon tear: an anatomic and clinical investigation. Arthroscopy. 2008;24:997-1004.

25. D'Addesi LL, Anbari A, Reish MW, Brahmabhatt S, Kelly JD. The subscapularis footprint: an anatomic study of the subscapularis tendon insertion. Arthroscopy. 2006;22:937-40.

26. Ide J, Tokiyoshi A, Hirose J, Mizuta H. An anatomic study of the subscapularis insertion to the humerus: the subscapularis footprint. Arthroscopy. 2008;24:749-53.

27. Richards DP, Burkhart SS, Tehrany AM, Wirth MA. The subscapularis footprint: an anatomic description of its insertion site. Arthroscopy. 2007;23:251-4.

28. Halder A, Zobitz ME, Schultz E, An KN. Structural properties of the subscapularis tendon. J Orthop Res. 2000;18:82934.

29. Gausden EB, McCarthy MM, Kontaxis A, Corpus KT, Gulotta LV, Kelly AM. Subscapularis tendon loading during activities of daily living. J Shoulder Elbow Surg. 2017;26:331-6.

30. Omi R, Sano H, Ohnuma M, et al. Function of the shoulder muscles during arm elevation: an assessment using positron emission tomography. J Anat. 2010;216:643-9.

31. Jang HS, Kong DH, Jang SH. Correlation between subscapularis tears and the outcomes of physical tests and isokinetic muscle strength tests. Clin Should Elbow. 2016;19:90-5. 


\section{견갑하건 부착부의 제1부착면에 대한 초음파 소견의 기술적 연구 \\ 소훈상* • 위찬구 • 소민수}

국립중앙의료원 관절센터, 정형외과, *연세대학교 원주의과대학 정형외과학교실

목적: 병변이 없는 견갑하건 부착부를 가진 환자를 대상으로 초음파를 통한 견갑하건의 부착부, 특히 제 1 부착면에 대한 초음파적 영 상 소견 및 그 크기를 기술하고 인구통계적 특성과의 상관관계를 분석하고자 하였다.

대상 및 방법: 2015년 3월부터 2017년 12월까지 견갑하건 부착부에서 병변이 없는 것으로 확인된 시행된 115예(평균 연령 53.4세, 범위 23-74세)를 최종 평가대상으로 하여 후향적 분석을 시행하였다. 초음파를 통한 견갑하건의 부착부에 대한 검사상 가장 상부에 위치하면서 제 2 부착면 이하 부착면들과 뚜렷하게 구별되는 넓고 평편한 형태와 상방으로 향하고 있는 제 1 부착면을 확인하였으며 제 1 부착면의 상완골 간부의 축에 대한 횡축과 종축상의 길이를 측정하였다. 또한 각 예의 나이, 성별, 키, 체중, 체질량지수 및 팔 길이 를 측정하였다.

결과: 초음파 검사를 통하여 측정된 견갑하건의 제1부착면의 평균 횡적 길이는 $12.75 \mathrm{~mm}$ (범위 $10.54-14.50 \mathrm{~mm}$, 표준편차 0.712), 평균 종적 길이는 $12.22 \mathrm{~mm}$ (범위 9.20-13.30 mm, 표준편차 0.888)였다. 성별간 견갑하건의 제1부착면의 크기는 횡적 길 이와 종적 길이 모두에서 남성에서 유의하게 큰 것으로 확인되었다 $(\mathrm{p}<0.001, \mathrm{p}=0.001)$. 양성의 선형 상관관계를 보이는 키, 체중, 체질량지수, 팔 길이 요소들 중 견갑하건의 제 1 부착면의 종적 및 횡적 크기 모두에서 키와 가장 강한 양성 선형관계를 보였고(횡적 길 이 $r=0.749, p<0.001$; 종적 길이 $r=0.642, p<0.001$, 체질량지수와는 약한 양성 선형관계를 보이는 것으로 분석되었다. 그 외 좌우 부위 및 나이는 제 1 부착면의 크기와의 통계적 유의성이나 선형 상관관계를 보이지는 않았다.

결론: 병변이 없는 견갑하건 부착부의 초음파적 영상 평가를 시행하여 그 부착부, 특히 가장 상부의 제 1 부착면의 구조적 및 형태적 특성을 확인할 수 있었다. 이는 견갑하건 파열에 대한 초음파 진단적 검사에 대한 해부학적 기초를 제공하게 될 것이다.

색인단어: 견관절, 견갑하건, 진단적 초음파

접수일 2018년 9월 25일 수정일 2018년 10월 22일 게재확정일 2018년 10월 26일

책임저자 손민수

04564 , 서울시 중구 을지로 245, 국립중앙의료원 관절센터, 정형외과

TEL 02-2262-4707, FAX 02-2278-9570, E-mail smsice125@naver.com, ORCID https://orcid.org/0000-0002-0012-595X 